Nur Çeku ${ }^{1}$

Haxhi Xhemajli ${ }^{2}$

\title{
CONSTITUTIONAL PRINCIPLES AND THEIR IMPACT ON THE ESTABLISHING OF THE CONSTITUTIONAL ORDER AND RULE OF LAW IN KOSOVO
}

UDK: $342.4(497.115)$

DOI: $10.31141 /$ zrpfs.2020.57.138.1079

Pregledni znanstveni rad

Primljeno: 15. veljače 2020.

Considered as a progressive document based on the models of the Western constitutions, the Constitution of the Republic of Kosovo has established the legal basis for a functional statethat respects rights and fundamental freedoms while guaranteeing the rule of law. In its provisions, the Constitution has laid down basic principles which serve as the foundation for Kosovo's constitutional order. In this regard, these constitutional principles have been further enshrined in the provisions of laws that emanate from the Constitution, and also have been established in the institutional mechanisms for its appropriate application. In addition, what played a prominent role in defining these principles was the impact of the Constitutional Court's case-law. Case-law has reaffirmed in many instances the tremendous importance of constitutional principles in enhancing the rule of law, protecting the rights of minority groups and other members of Kosovo's society, and the right to freedom of belief and secularism by implementing the most modern European standards in human protection. Hence, this paper analyzess the impact that constitutional principles have had on defining the structure of the state, guaranteeing the rule of law, protection of human rights and establishing Kosovo as a multi-ethnic society. Likewise, it examines the case-law of Kosovo's Constitutional Court by providing some of the most prominent cases.

Key words: Constitution, constitutional principles, case-law, Constitutional Court, rule of law, affirmative action programs, human rights

1 Nur Çeku is a Ph.D. Candidate at the Faculty of Law, University of Prishtina. His research interests include, constitutional law and democratic governance, rule of law, parliamentary oversight and protection of whistleblowers. He has published in the fields of parliamentary oversight of security sector, legal aspect of data protection and protection of whistleblowers. Email address: nurceku@gmail.com

2 Haxhi Xhemajli is a Ph.D. Candidate at the Faculty of Law, University of Maribor, Slovenia. He holds a M.S. in Civil Law and an LL.M. in Democratic Governance and Rule of Law, as well as a Certificate on Legal Pedagogy and Instruction from Claude W. Pettit College of Law, Ohio Northern University. His research interests include, private law, enforcement procedure law, rule of law, and prisoners' rights. He has published in the fields of legal aspects of data protection, treatment of prisoners and compensation of the victims of sexual violence. E-mail address: haxhi.xhemajli@gmail.com 


\section{INTRODUCTION}

The history of the establishment of Kosovo as a state has gone through a very distinct and specific process, and as a result, it is often referred to as a "sui generis" state. However, Kosovo is not a "sui generis"state, rather the process of its independence was constructed that way as to be irreversible in similar cases. There is no doubt that this "sui generism" has at the same time influenced the organization and constitutional model of Kosovo. The Constitution of the Republic of Kosovo (henceforth: "CRK") it is the supreme law that has laid down the legal basis for the function of the state, and which includes basic principles for guaranteeing the rule of law.

The adoption of the CRK is preceded by different phases. The process began with negotiation in Vienna in 2006 between Pristina and Belgrade. The Vienna talks derived from the report of Mr. Kai Eide in 2005. ${ }^{3}$ As a leader of these negotiations, Martii Ahtisaari managed to derive the elements for what came to be known as the Ahtisaari Plan. ${ }^{4}$ The Ahtisaari Plan or Comprehensive Proposal for the Kosovo Status Settlement (henceforth: "CPKSS") of 26 March 2007, is the basic document which set out the fundamental principles of what Kosovo's future governance should be. Even though the CPKSS does not prescribe a complete Constitution, it defines the key elements that must form part of that Constitution. ${ }^{5}$

Another equally important step is the moment Kosovo's Declaration of Independence was signed on 17 February 2008. This document reflects the will of the people and is in full accordance with the recommendations of UN Special Envoy Martii Ahtisaari and his Comprehensive Proposal for the Kosovo Status Settlement. The Declaration of Independence, solemnly proclaimed fundamental principles of the rule of law which were to be integrated into the CRK. That is precisely why the Declaration of Independence is considered as a basic norm of the CRK.

The CRK, just like other legal acts that referred to Kosovo's status, held in itself, the secret tension, balancing the demands of the majority of people for independence with those who did not support Kosovo's bid for independence. In addition, the CRK, has integrated these contradictions which lie "tacitly" among its provisions, and thus, slowly creating the constitutional culture of respect for the rule of law.

In sum, all these phases have led to the establishment of a new state as a multi ethnic society, with full respect for the rule of law, human rights and fundamental freedoms. This paper will provide an overview of the basic constitutional principles and their role in guaranteeing the rule of law, discuss the goal that the CRK was designed to accomplish, and examine the relevant case-law of the Kosovo's

3 Mr. Kai Eide was appointed as a Special Envoy by the UN Secretary General Mr. Kofi A. Annan to undertake the comprehensive review of the situation in Kosovo.

${ }^{4}$ Galluci,M.,Gerard.(2011)The AhtisaariPlan and North Kosovo, Transconflict,p.4, availableat:http:// www.transconflict.com/10/wp-content/uploads/2011/11/PolicyPaper_AhtisaariPlanNorthKosovo.pdf

5 See United Nations, Security Council (2007) Comprehensive Proposal for the Kosovo Status Settlement, ANNEX I, available at: https://www.securitycouncilreport.org/atf/cf/\%7B65BFCF9B-6D274E9C-8CD3-CF6E4FF96FF9\%7D/Kosovo\%20S2007\%20168.Add1.pdf 
Constitutional Court that has thoroughly treated, preserved, clarified and advanced these principles in plethora of cases.

\section{CONSTITUTIONAL DEFINITION OF STATE}

The CRK was adopted on 9 April 2008. In the context of creation of the independence of the state, CRK along with the Declaration of Independence marks the materialization of the process of establishing the Republic of Kosovo as an independent country. The CRK is entirely modeled according to the principals, standards, and values of Western constitutionalism. As a basic document, the CRK promotes democratic values based on constitutional democracy, ensuring the equality and respect for human rights, and fundamental freedom for all citizens.

In its basic provision, the CRK proclaims the definition of state. Therefore, the CRK has established Kosovo as an independent, sovereign, democratic, unique and indivisible state. ${ }^{6}$ Based on this provision, Kosovo is a unique state either in its legal entity sense or geographical one. Every part of Kosovo's territory is an indivisible part of the domestic legal order and all institutional mechanisms are obliged to enforce the constitution and Kosovo's laws.

As to the definition of state, it is without any doubt that its indivisibility constitutes one of the basic principles of the CRK. ${ }^{7}$ It is worth mentioning, however, that this principle serves a protective legal mechanism for any possible territorial exchange between Kosovo and any other state. The purpose of this principal is to designate a threshold concerning the majority of the votes needed in such cases. In order for an agreement to be constitutionally acceptable, this principle implies that the exchange of territories has to go through the ratification process with $2 / 3$ (two thirds) of the votes of all members of the Parliament. ${ }^{8}$

\section{FORM OF GOVERNANCE AND SEPARATION OF POWERS}

The form of governance and separation of powers is a fundamental principle in most states' constitutions. According to this principal, most states designate their form of governance whether they want to be a parliamentary system, presidential system or semi-presidential system. Provisions of the CRK provide that Kosovo is a

${ }^{6}$ Article 1(1) of the Constitution of the Republic of Kosovo, available at: http://www.kryeministri-ks. net/repository/docs/Constitution1Kosovo.pdf

7 Article 1(3) of the Constitution stipulates that, "The Republic of Kosovo shall have no territorial claims against, and shall seek no union with, any State or part of any State."

8 Article 18(1), CRK. This provision of the CRK serves as a safeguard for limiting competences towards any territorial exchange. Therefore, in recent years, in Kosovo, has been a huge debate on the possibility of a final agreement between Kosovo an Serbia that would include land swap. 
Democratic Republic based on the principal of separation of powers and the checks and balances among them. ${ }^{9}$

Therefore, considering the model adopted by the CRK, Kosovo is a country with a parliamentary system, similiar to other Western parliamentary systems.As professors Jackson \& Tushnet have explained, "Many western democracies use a parliamentary system in which the executive officers of the government are selected by and accountable to an elected legislature, rather than thepresidential system in which the chief executive officers is elected by the same consitutuency that chooses the legislative branch." ${ }^{10}$ Likewise, Kosovo's parliamentary system has enshrined basic features of western parliamentary systems such as, election of the government and overseeing their work and other public institutions that are accountable to the parliament. Arguments that Kosovo is a state with parliamentary system lies on the provisions of the CRK, designating that the Government is responsible for implementation of laws and state policies and is subject to parliamentary control. ${ }^{11}$

This basic principal [separation of powers] means that all institutions in Kosovo, including legislative, executive, president, and judiciary exercise their competencies expressis verbis by the provisions of the constitution. This is related also to another basic principal that is the principal of enumeration of the constitutional jurisdiction. Through this principal, competencies of public institutions are strictly delineated in the constitution, and they cannot exceed them. For instance, the Assembly of the Republic of Kosovo has fourteen constitutional competencies plus one that was added by the $23^{\text {rd }}$ amendment to the constitution, ${ }^{12}$ the Government of the Republic of Kosovo has eleven constitutional competencies, the President of the Republic of Kosovo has thirty constitutional competencies and cannot exercise, for example thirty one. ${ }^{13}$

In addition to the constitutional provisions, this principal has been also reaffirmed by the case-law of the Constitutional Court (henceforth: "The Court"). In its decision, the Court has pointed out that the institutional organization in the Republic of Kosovo is based on democratic governance, separation and control of powers, and rule of law. Accordingly, the Courtconcluded that each branch of the states power must act in compliance with the CRK and within the scope of the constitution, thus guaranteeing the principle of the separation of powers and

\footnotetext{
9 Article 4(1) CRK.

10 Jackson, C., Vicki \& Tushnet, Mark. (2014) Comparative Consitutional Law, 3rd ed., University Casebook Series, p. 834.

11 Article 4(4) CRK.

12 Article 65(1) CRK. Amendment $23^{\text {rd }}$ to the CRK has entered into force by the Decision No. 04V-553, 14 March 2013 of the Assembly of Kosovo. So, actually Assembly of Kosovo/Parliament has entirely fifteen constitutional competencies.

13 Article 93, and Article 84, CRK.
} 
democratic values of governance. ${ }^{14}$ Finally, the principal of the seperation of powers has been ranked to the democratic value, within the domestic constitutional order.

\section{THE SUPREMACY OF THE CONSTITUTION}

The CRK is considered fundamental and superior law. Such supremacy is explicitly recognized by its provisions. ${ }^{15}$ In terms of supremacy, the CRK is not on the same level as a statute, which is not the same as a regulation. But, previously, as a result of the UN administration and until the end of the international supervision of independence of Kosovo in 2012, the CRK recognized the Comprehensive Proposal for the Kosovo Status Settlement as a superior law above all other legal acts within the domestic legal system, including the CRK itself. ${ }^{16}$ Currently, the CRK specifically provides that international laws and treaties supersede the laws of Kosovo, but not necessarily the CRK. ${ }^{17}$ Therefore, reading together Article 19 and 22 of the CRK, we can conclude that in case of conflicts between legislative acts and international instruments, the latter prevail.

In this regard, in Kosovo's constitutional system, the entire legal norms submit to the supremacy of the constitution, and when an issue falls within the framework of the constitution, it cannot be amended, undermined or transformed through an act with a lower legal power as the law. This supremacy of the constitutional norm is well brought out in the recent case - Law of the Court reaffirming that all other legal acts should be in compliance with it. ${ }^{18}$ However, the enforcement of this principle cannot be characterized only as normative, as indicated earlier, but also in the functional sense.

In the functional sense, the supremacy of the constitutional norm implies that all higher public officials should adjust their actions to the constitution, acting otherwise

14 See Judgment in Case No. KO43/19, dt. 27 June 2019, Aplicants Albulena Haxhiu, Driton Selmanaj and thirty other deputies of the Assembly of the Republic of Kosovo, paragraph, 74 and 77, available at: https://gjk-ks.org/wp-content/uploads/2019/06/ko_43_19_agj_ang.pdf; Additionally, in paragraph 73 of the same Judgment, the Court has reiterated inter alia that, "...within the framework of Article 4 of the CRK, which defines the form of governanceand the separation of power, the Assembly as a representative of the people, in accordance with paragraph 2 of Article 4 of theCRK, is at the same time the highest body exercising legislative power; in accordance with paragraph 3 of Article 4 of the CRK, the President of the Republic of Kosovo represents the unity of people, as well as a legitimate representative of the country inside and outside, and is the guarantor of the democratic functioning of the institutions of the Republic of Kosovo, as well as in accordance with paragraph 4 of Article 4 of the CRK, the Government of the Republic of Kosovo is responsible for the implementation of laws and state policies and is subject to parliamentary control by the Assembly."

15 See Article 16(1) CRK.

16 Article 143(1)(2)(3) CRK. But, this Article has been deleted by the end of the international supervision of independence of Kosovo through Amendment 4 to the CRK, by the Decision of the Assembly of Kosovo No. 04-V-436, dt. 7 September 2012. See inter alia Law No. 04/L-115 on Amending and Supplementing the Laws related to the ending of International Supervision of Independence of Kosovo, available at: https://gzk.rks-gov.net/ActDetail.aspx?ActID=2840

17 Article 19(1)(2) CRK.

18 See Judgment in Case No. KO43/19, dt. 27 June 2019, paragraph 69. 
would lead to legal consequences. A well-known case of the functional supremacy is the removal of the former President of Kosovo from office who committed a serious violation of the Constitution. In this case, the Court ruled that there was a serious violation of the CRK namely, Article 88.2, by the former President Mr. Fatmir Sejdiu who held the office of President of the Republic and at the same time the office of Chairman of his political party. ${ }^{19}$ However, the Court has established a practise that whatever the public position, the violation of the supremacy of the constitutional norm by a public official amounts to the undermining of the basic democratic values enshrined in the provisions of the CRK.

\section{EQUAL TREATMENT/AFFIRMATIVE ACTION PROGRAMS}

The CRK has established the principal of equal treatment by proclaiming equal rights for minority groups in Kosovo. Such equality, has been implemented through affirmative action programs by applying a neutral policy to ensure that opportunities are open to everyone regardless of race, gender, religion, or any demographic attribute. ${ }^{20}$ This principal is namely the characteristic of the new countries which were under the international administration, such as the case of Kosovo. Kosovo, as a newly established democracy, had been for more than a decade under the United Nations Interim Administration, (henceforth: UNMIK). In its basic sense, affirmative action relies on giving to someone certain rights much more than they actually deserve by implementing quotas for groups of minorities as they relate to employment, public representation, education etc.

Through this principal, minority groups in Kosovo have been given extended rights, particularly in the aspect of participation in public institutions and decisionmaking. Therefore, the constitutional order exists to authoritatively and legitimately maintain just social relations, defined by a set of principles in the constitutional that reflects the moral climate of the society. ${ }^{21}$ Such principals, the CRK has implemented in favor of the minority groups when comparing to Kosovo Albanians as the majority who constitute $90 \%$ of the population. When talking of the public

19 See Judgment in Case No. KI 47/10, date 28 September 2010, Applicants Naim Rrustemi and 31 other Deputies of the Assembly of the Republic of Kosovo, p. 12, available at:https://gjk-ks.org/wpcontent/uploads/vendimet/ki_47_10_eng_2.pdf; Additionally, the Court held that, "When the President of the Republic allows a political party to claim that he or she is the Chairman of their political party even under circumstances where he or she as Chairman wi 11 not make any active decisions on behalf of the party, he or she is exercising a political activity or at least allowing the political party to "make use of of his name and position as President of the Republic." See paragraph 67.

20 Yu, Ho., Chong \& Cheung, Tung., Kwok. (2017) Rethinking the Dworkinian Forward-Looking Approach: is Affirmative Action Compatible with Fairness, European Journal of Social Sciences Education and Research, Sep. Dec. 2017 Vol.11 Nr. 2, p. 167 available at: https://www.researchgate. net/publication/320586791_Rethinking_the_Dworkinian_Forward-Looking_Approach_is_Affirmative_ Action_Compatible_with_Fairness

21 DeBell, Matthew. (2006) Affirmative Action in Higher Education: Insults, Preferences, and Affirmative Action in Higher Education: Insults, Preferences, and the Dworkin Defense, American National Election Studies, Stanford University, Volume 85, Issue 2, p. 518 available at: https://digitalcommons.unl. edu/cgi/viewcontent.cgi article $=1119 \&$ context $=$ nlr 
representation, one may take the example of the distribution of parliamentary seats. In this respect, 20 of the 120 seats in the Assembly of Kosovo are guaranteed for representation of minorities. For instance, if Serb Community takes part in election, 10 seats in the Assembly are guaranteed for them regardless of whether they have won 10 seats in the election. ${ }^{22}$

Throughout the CRK, exists provisions that stipulate affirmative action programs for the minority groups in Kosovo. Similarly, chapter three of the CRK, determines additional rights for the non-majority groups by extending, adding and supplementing the provisions of all other basic human rights guaranted by the contititution. ${ }^{23}$ In addition, the protection of minorities is, as Dworkin aknowledges, "central to any theory of justice" and what matters he says, "is whether persons are treated as equals with the same respect and concern as anyone else." ${ }^{24}$ And in domestic legal order, such protection minority rights is enshrined in the provisions of the constitution and other legislation called, "Legislation of Vital Interests." 25 This legislation provides affirmative measures for minorities, and theselaws require for their adoption, amendment or repeal both the majority of the Assembly deputies present and voting and the majority of the Assembly deputies present and voting holding seats reserved or guaranteed for representatives of communities that are not in the majority. ${ }^{26}$ As currently regulated, none of the laws of vital interest may be submitted to a referendum. ${ }^{27}$ Hence, the prohibition of conducting referendum is precisely an affirmative measure that laws or provisions of such laws [vital interest] not be prevailed by the majority vote of citizens.

Additionally, even in the case of amending the constitution there exists an affirmative mechanism which makes the procedure for amending the constitution difficult. This highly rigid procedure requires both the majority (two thirds) of the Assembly members present and voting and the majority of the Assembly members present and voting holding seats reserved or guaranteed for representatives of minority groups that are not in the majority. ${ }^{28}$ Affirmative actions are also inherent in

22 See Article 64 (2)(1)(2) CRK.

23 For further information see Chapter 2, CRK [Fundamental Rights and Freedoms] and Chapter 3 [Rights of Communities and Other Members].

24 Freeman, Michael. (2014) Lloyd's Introduction to Jurisprudence, Sweet and Maxwell, 9th ed, pp. 506-507.

25 Laws that constitute Legislation of vital interest are,"(1) Laws changing municipal boundaries, establishing or abolishing municipalities, defining the scope of powers of municipalities and their participation in intermunicipal and cross-border relations; (2) Laws implementing the rights of Communities and their members, other than those set forth in the Constitution; (3) Laws on the use of language; (4) Laws on local elections; (5) Laws on protection of cultural heritage; (6) Laws on religious freedom or on agreements with religious communities; (7) Laws on education; (8) Laws on the use of symbols, including Community symbols and on public holidays."

26 See Article 81 CRK.

27 Id. Article 81(2) CRK.

${ }_{28}$ Recently, one of the greatest challenges regarding the amending of the CRK, has been changing the mandate of the Kosovo Security Forces in order to equip with military mandate. In this regard, for many years members of the Assembly belonging to the Serb community did not vote such amendings, and therefore, the mandate of the Security Force has been advanced and altered by enacting entirely new package of laws. 
the structure of the institutional establishment of the three branches of government, and other independent institutions. At the level of legislative branch, the CRK has established the standing parliamentary committee called "the Parliamentary Committe for the Rights and Interests of Communities." The committee is mainly composed of members of the minority groups. In its mandate, among other things, the committee has the autorization to make recommendations, and proposals for draft-laws, or propose other measures through which the rights and interests of minorities are adequately addressed.Also in the composition of the presidency of the Assembly,of thefive members of the presidency, two of them must belong to the minorities. ${ }^{29}$

At the level of Government composition, the CRK determines that at least one minister should be from theSerb minority and one form other minority groups. ${ }^{30}$ In the case that the number of ministries is more than twelve,the Government will have a third minister representing a Kosovo nonmajority community. ${ }^{31}$ Another affirmative measure relates to the selection of the ministers from minority groups as members of the executive. Therefore, their selection is determined after consultations with parties, and coalitions or groups representing minorities in Kosovo. In this regard, if the candidates for the position in government are not elected members of the parliament, it is compuslory to have the endorsement of the majority of Assembly members belonging to parties, coalitions, citizens' initiatives and independent candidateshaving declared themselves to represent the community concerned. ${ }^{32}$ Such constitutional provision prohibits any possibility of appointing ministers (i.e., from majority Albanians) other than members of minorities, and who has no legitimacy to represent the minorities. Equally, in the organization of the judiciary, it is stipulated by the CRK that some affirmative measures exist that enablerepresentation of minority groups in the Kosovo Judicial Council (henceforth: KJC). As an independent constitutional organ, the $\mathrm{KJC}$ is responsible for appointment and recruitment of judges, and it is composed of thirteen members, two of them belong to the Serb community and two others from the other members of the community. Similarly, in the aspect of representation of the judges, whether in the supreme court, apellate court or first instance courts, fifteen percent of the judges should be from the minority groups in Kosovo. ${ }^{33}$ That is also apparent in the composition of the Constitutional Court where out of nine judges of the Court, two of them must come from the minorities. ${ }^{34}$

29 See Article 67(1)(3)(4) CRK.

30 Pursuant to Article 64(1)(2) of the CRK, the minority groups in Kosovo are, "Serbs, Bosniaks, Ashkali, Turkish, Egyptians, Gorani and Roma."

31 Article 96, CRK.

32 Id. Article 96(4)(5) CRK.

33 See Article 103, and Article 108(6)(3)(4) CRK. With regard to the composition of the KJC, see inter alia Article 8(3)(4) of the Law No. 06/L-055 on Kosovo Judicial Council, Official Gazette of the Republic of Kosovo, No. 23/26 December 2018, Pristina, available at: https://gzk.rks-gov.net/ActDetail. aspx?ActID $=2713$

${ }^{34}$ See Article 114(3) CRK. 
Finally, protection and affirmative treatment of minorities is regarded as a democratic value in the multi-ethnic Kosovo. The definition of Kosovo as a multiethnic societyhas been accomplished by giving all its communities equal rights and opportunities. Such treatment has been reaffirmed also by the Court where inter alia has concluded that, ".... a prerequisite for a pluralist and genuinely democratic multiethnic society, be it a country, region, municipality or other territorial unit, is nonmajority community participation in the political, social, economic, and cultural life in order to develop a sense of belonging to and having a stake in that sociaty." ${ }^{35}$ In this regard, Kosovo has implemented as a fundamental value protection and advancement of the rights and interests of all communities, ensuring that none of communities will be put in a privileged position over another.

\section{DIRECT APPLICABILITY OF INTERNATIONAL AGREEMENTS AND INSTRUMENTS}

As stated previously, the constitutional system is based on the values of democracy, human rights and the rule of law.The constitutional principal of direct applicability of international agreements and instruments, therefore, constitutes the protection of human rights and fundamental freedoms. However, it was the need for protection of human rights that brought about the intervention of international community and establishmentof the international administration in Kosovo in 1999. Immediately, after the establishment of the international administration,the construction of the domestic legal order began. In this period, achallenging issue was to determine which legislationwas applicable. To avoidthat confusion, UNMIK enacted Regulation 1999/24which determined the law applicable in Kosovo. According to the UNMIK Regulation the law applicable was (a) the regulations promulgated by the Special Representative of the Secretary-General and (b) the law in force in Kosovo on 22 March 1989.36

The UNMIK Regulationswere the first legal acts in the post bellum Kosovo to lay down the principals for protection of human rights and fundamental freedoms, and also to give effect to international agreements and standards within

35 See Judgment in Case No. KO 01/09, date 18 March 2010, Applicants Qemajl Kurtishi v. Municipal Assembly of Prizren, paragraph 52, available at:https://gjk-ks.org/wp-content/uploads/ vendimet/ko_01_09_Ven_ang.pdfIn thiscase, the Court had to consider to what extent Article 7 of the Municipal Statute of Prizren complied with the law and international standards. Likewise, the Court found that the Municipal Assembly, when making the decision on adopting Article 7 of its Statute, imposed an emblem which cannot be considered as a common symbol of all Prizren communities, and outweighed the identity of the ethnic Albanian Community over the identity of other Communities in Prizren. Thereby, the Court found that the Municipal Assembly violated the Constitution. Finally, the Court concluded that the Municipality of Prizren did not have any or any proper regard to the fundamental rights and freedoms granted by the Constitution when dealing with the right of the non-majority Communities to preserve, maintain and promote their identity. See paragraphs 50, 55 and 56 of the Judgment in Case No. KO 01/09, date 18 March 2010, Qemajl Kurtishi v. Municipal Assembly of Prizren.

36 See Article (1)(1)(a)(b), UNMIK Regulation 1999/24, 12 December 1999, available at: https:// unmik.unmissions.org/sites/default/files/regulations/02english/E1999regs/RE1999_24.htm 
the domestic legal order. ${ }^{37}$ That might be considered as a "first moment" towards application of such standards in the newly established legal order. In addition to the UNMIK Regulation, the necessity to transform and establish the new interim institutions in Kosovo, required the adoption of the new legal basis. Thislegal basis was the Constitutional Framework for Provisional Self-Government (henceforth: Constitutional Framework) promulgated by UNMIK Regulation2001/9. The Constitutional Framework has stipulated that, "All persons in Kosovo shall enjoy, without discrimination on any ground and in full equality, human rights and fundamental freedoms." 38 Accordingly, the Constitutional Framework made provisions for the rights and freedoms directly applicable in Kosovo. In this regard, the provisional institutions of self-government were obliged to observe and ensure the application of such internationally recognized standards and instruments. ${ }^{39}$ The provisions of the Constitutional Framework were a step forward in improving the protection of rights and fundamental freedoms. Therefore, the Constitutional Framework has made all these international standards self-applicable in the legal order. After a long process under the international administration, Kosovo adopted its Constitution. The CRK, following the tradition of the Constitutional Framework and Ahtisaari Plan, hasincorporated the basic legal and institutional principles regarding human rights as well. The CRK, throughout its content includes important provisions with regard to the protection of human rights and fundamental freedoms. In this regard, the CRKthrough Art. 22, has incorporated international standards into the law of Kosovo at the Constitutional level, and, therefore, these conventions have direct applicability in Kosovo and they have priority over provisions of laws

37 The UNMIK Regulation 1999/24, has listed the following international instruments in the field of protection of human rights, (1) The Universal Declaration on Human Rights of 10 December 1948; (2) The European Convention for the Protection of Human Rights and Fundamental Freedoms of 4 November 1950 and the Protocols; (3) The International Covenant on Civil and Political Rights of 16 December 1966 and the Protocols; (4) The International Covenant on Economic, Social and Cultural Rights of 16 December 1966; (5) The Convention on Elimination of all Forms of Racial Discrimination of 21 December 1965; (6) The Convention on Elimination of all Forms of Discrimination Against Women of 17 December 1979; (7) The Convention Against Torture and Other Cruel, Inhumane or Degrading Treatment or Punishment of 17 December 1984; and (8) The International Convention on the Rights of the Child of 20 December 1989;

38 See Article 3(1) of the Constitutional Framework for Provisional Self-Government, available at: https://www.esiweb.org/pdf/bridges/kosovo/12/1.pdf

39 See Article 3(2)(3) of the Constitutional Framework. Additionally, in the Chapter 3, the Constitutional Framework has incorporated the following international standards, such as (1) The Universal Declaration on Human Rights; (2) The European Convention for the Protection of Human Rights and Fundamental Freedoms and the Protocols; (3) The International Covenant on Civil and Political Rights and the Protocols; (4) The International Covenant on Economic, Social and Cultural Rights; (5) The Convention on Elimination of all Forms of Racial Discrimination; (6) The Convention on Elimination of all Forms of Discrimination Against Women; (7) The European Charter for Regional or Minority Languages; and (8) The Council of Europe's Framework Convention for the Protection of National Minoritites; 
and other acts of public institutions..$^{40}$ To date, Kosovo has not acquired membership in any international institutions either United Nations or Council of Europe, and therefore what turns out as an issue is the fact whether these instruments can be directly applicable into domestic law.

According to the treatises doctrine of "self-application" the direct applicability it is usually reserved for some of the very specific provisions, for specific cases ${ }^{41}$ But, to enable the direct application, and avoid any misconception, the CRK, contains a very specific provision in Art. 53. This provision provides that, "human rights and fundamental freedoms guaranteed by this Constitution shall be interpreted consistent with the court decisions of the European Court of Human Rights (henceforth: "ECtHR.") According to this provision, it is apparent that the case-law of the ECtHR is compulsory for all public authorities in Kosovo. In this regard, as the Court has proclaimed in its case-law, "the Decisions which emanate from the courts that adjudicate on these Conventions, principally the ECtHR sitting in Strasburg, aid and assist not only all the Courts of Kosovo but other State organs as to how fundamental rights and freedoms must be interpreted and applied in Kosovo." ${ }^{2}$ Therefore, the Court has actively refered to the case-law of the ECtHR, and as a result, most of the decisions of the Court have integrated some of the european judicial standards into the domestic constitutional adjudication.

\section{JUDICIAL REVIEW OF THE LEGISLATION}

The principal of judicial review of legislation is another essential principal that the CRK has developed. Constitutional judicial review implies the review of the constitutionality of legislation adopted by the Assembly. Judicial review is a fundamental component of a modern constitutional democracy, due to the fact that constitutional judicial review involves the authority of judiciary to review legislation and other acts of the administration, and declare void those found in conflict with the constitution, or other declarations of basic rights. ${ }^{43}$ The CRK, as

40 See Article 22 and the following sub-paragraphs of the CRK. For a deeper understanding see the content of this Article which enumerates all international agreements and instruments that have direct applicability in domestic legal system including, (1) Universal Declaration of Human Rights; (2) European Convention for the Protection of Human Rights and Fundamental Freedoms and its Protocols; (3) International Covenant on Civil and Political Rights and its Protocols; (4) Council of Europe Framework Convention for the Protection of National Minorities; (5) Convention on the Elimination of All Forms of Racial Discrimination; (6) Convention on the Elimination of All Forms of Discrimination Against Women; (7) Convention on the Rights of the Child; and (8) Convention against Torture and Other Cruel, Inhumane or Degrading Treatment or Punishment;

41 Weller, Marc. (2009) Contested Statehood: The International Administration of Kosovo's Struggle for Independence, Oxfort University Press, p. 398.

42 See Judgment in Case No. KO 01/09, date 18 March 2010, Applicants Qemaj1 Kurtishi v. Municipal Assembly of Prizren, paragraph 34.

43 Tridimas, George. (2009) Constitutional Judicial Review and Political Insurance, European Journal of Law and Economics, DOI: 10.1007/s10657-009-9112-z, p. 97, available at: https://www. researchgate.net/publication/225759546_Constitutional_judicial_review_and_political_insurance 
with other constitutions in new democracies has granted the authority of judicial review to the Constitutional Court. Pursuant to the CRK provisions, the Court is the final authority for interpretation of the Constitution and the compliance of laws with the Constitution. ${ }^{44}$ It is worth mentioning that the Constitutional Court is not a court of appeal or a court of fourth instance. In this regard, the CRK guarantees two fundamental rights: (a) judicial protection of Constitutional rights and (b) the right to an effective remedy to redress any violations of these Constitutional rights. ${ }^{45}$

With regard to the competencies for referring the matter before the Court, in terms of the compatibility of the legislation and other acts of public institutions with the constitution, the CRK has authorized the following institutions, such as (a) the President; (b) the Government; (c) the Assembly of Kosovo; (d) Ombudsperson; and (e) a municipality.In order to prevent the effect of an adopted law which seems to be unconstitutional, the CRK stipulates that ten or more deputies of the Assembly, within eight days from the date of adoption, have the right to contest the constitutionality of that law as regards its substance and the procedure followed. ${ }^{46}$ The case-law of the Court has been laden with plenty of cases regarding judicial review of the legislation, and it has also established some basic principles which should be considered by the legislator when enacting the laws. For instance, the Court proclaimed that there are restrictions on the right and authority of the Assembly to enact legislation, stating that, the legislation must comply with the Constitution and the principles of the Constitution, and also the legislation which affects individuals, corporate or personal, must have a legitimate aim and must be proportional to the rights of all citizens of Kosovo. ${ }^{47}$ Recent case-law of the Court shows that the Court may invalidate a law in its entirety after conducting the constitutional review and finding the law unconstitutional. An important case to illustrate this power is the constitutional review of the Law No. 06/L-145 on the Duties, Responsibilities and Competences of the State Delegation of the Republic of Kosovo in the Dialogue Process with the Republic of Serbia (henceforth: Law No. 06/L-145). In this case, as the Court found the incompatibility of the main articles of the Law No. 06/L-145

${ }^{44}$ See Article 112(1) CRK.

45 See Article 54 CRK.

46 See Article 113(2)(4)(5) CRK. In addition to the authorized institutions above, the CRK provides that, "(1) Thirty or more deputies of the Assembly are authorized to refer the question of whether the President of the Republic of Kosovo has committed a serious violation of the Constitution. (2) Individuals are authorized to refer violations by public authorities of their individual rights and freedoms guaranteed by the Constitution, but only after exhaustion of all legal remedies provided by law, and (3) The courts have the right to refer questions of constitutional compatibility of a law to the Constitutional Court when it is raised in a judicial proceeding and the referring court is uncertain as to the compatibility of the contested law with the Constitution and provided that the referring court's decision on that case depends on the compatibility of the law at issue."

47 See Judgment in Case No. KO 119/10, date 8 December 2011 Applicant Ombudsperson of the Republic of Kosovo, paragragh 54, available at:https://gjk-ks.org/wp-content/uploads/vendimet/gjk ko_119_10_ang.pdfIn this case, the applicant [Ombudsperson] requested the constitutional review of Article 14, paragraph 1.6, and Articles 22, 24, 25 and 27 of the Law on Rights and Responsibilities of the Deputy, No. 03/L-111, of 4 June 2010. 
with the relevant articles of the Constitution, the Court declared that the Law No. 06/L-145, in its entirety, is incompatible with the Constitution. ${ }^{48}$

Finally, as the final authority for interpretation of the constitution and the compliance of laws with the constitution, the CR Kalso has the authority to review the decrees of the president, decisions of the Government ${ }^{49}$ and statutes of municipalities. Such authority is considered an ex-post jurisdiction of the Court, therefore, ensuring the compliance of the legislation with the supreme law, the CRK. Whilst the ex-ante jurisdiction of the Court relates to the constitutional review of the draft-legislation. In this regard, prior assessment of draft-laws happens before their adoption by the Assembly to ensure whether such legislation restrict or diminish the human rights guaranteed by Chapter 2 and 3 of CRK.

For instance, an ex-ante constitutional review is the case of Amendment 24 to the CRK which determines the mandate, jurisdiction, composition and the establishment of the Specialist Chambers and the Specialist Prosecutor's Office. In this regard, the President of the Assembly of the Republic of Kosovo referred the Amendment $24^{50}$ to the CRK to the Constitutional Court proposed by the Government of the Republic of Kosovo. The subject matter of the referral was the prior assessment by the Court whether the proposed Amendment [24] to the Constitution had diminished any of the rights and freedoms guaranteed by Chapter 2 of the Constitution. Accordingly, the Court ruled that, "the proposed Amendment No. 24 does not diminish the constitutional rights guaranteed by Chapter 2 of the Constitution as well as under Chapter 3 of the Constitution and its letter and spirit as established in the Court's case law. Therefore, the proposed Amendment is in compliance with the Constitution." ${ }^{51}$

48 See Judgment in Case No. KO43/19, dt. 27 June 2019, Aplicants Albulena Haxhiu, Driton Selmanaj and thirty other deputies of the Assembly of the Republic of Kosovo, paragraph 108.

49 One of the most recent cases where the Court declares as unconstitutional the Decision of the Government is the Judgment in Case No. 54/20, date 31 March 2020 Applicant President of the Republic of Kosovo. The subject matter of the Referral was the constitutional review of Decision No. 01/15 of the Government of the Republic of Kosovo of 23 March 2020. However, the constitutional question that the Judgment entailed was the compatibility with the Constitution of the challenged Decision of the Government, namely whether by its issuance the Government had limited the fundamental rights and freedoms guaranteed by the Constitution in accordance with the law or beyond the powers provided by law. Finally, the Court decided that, "Decision No. 01/15 of the Government of the Republic of Kosovo of 23 March 2020, is not in compliance with Article 55 [Limitations on Fundamental Rights and Freedoms] in conjunction with Articles 35 [Freedom of Movement], 36 [Right to Privacy] and 43 [Freedom of Gathering] of the Constitution, with Articles 8 (Right to respect for private and family life) and Article 11 (Freedom of assembly and association) of the ECHR, as well as Article 2 (Freedom of movement) of Protocol No. 4 of the ECHR." available at:https://gjk-ks.org/en/decisions-from-the-review-sessions-heldon-30-and-31-of-march-2020/Therefore, the Court declared the Decision incompatibil with the CRK.

50 See Amendment No. 24 to the Constitution of the Republic of Kosovo, Official Gazette of the Republic of Kosova, No. 20/05 August 2015, Prishtina, available at: https:/gzk.rks-gov.net/ActDetail. aspx?ActID=3702

51 See Judgment in Case No. KO26/15, date 15 April 2015, paragraph 105 and p. 18, available at: https://gjk-ks.org/wp-content/uploads/vendimet/KO26-15_ANG.pdf 


\section{RIGHT TO FREEDOM OF RELIGION AND SECULARISM}

The CRK assures freedom of belief, conscience, and religion. This is among the most important principles that the CRK has accomplished in its provisions. The CRK protects the right to accept, manifest and express personal beliefs and the right to join or refuse membership in a religious community or group..$^{52}$ In addition to protection of the right to accept and express personal beliefs, the CRK allows the passing of laws limiting freedom of belief, conscience, and religion only when such manifestation would harm public safety, order, health, or the rights and freedoms of others. ${ }^{53}$

This principal [right to freedom and religion] does not stand alone, but interacts with another principal enshrined in the Art. 8 of the CRK which determines Kosovo as a secular state and neutral in matters of religious beliefs. Human rights, in general, were something that those who drafted the Constitution of the Republic of Kosovo took very seriously, and tried to implement the most modern European standards in human protection. ${ }^{54}$ Considering the features of Kosovo's society with a number of communities embracing different religions and beliefs, the constitutional principle of secularism is an unamandable principle of the CRK.However, the state has an obligation to give expression of the rights granted to communities and their members under the Constitution. In line with this obligation, Kosovo, took a positive obligation to promote or facilitate the exercise of fundamental human rights, the free exercise of religion is deemed to require governmental facilitation, so long as this facilitation is not discriminatory and respects state neutrality. ${ }^{55} \mathrm{In}$ this regard, religious communities will be separated from public authorities and, therefore, public authorities will promote, recognize and fascilitate respect among religions. The practice of expelling religion from the public sphere, summed up as laïcitélsecularism, became a constitutional value and was written into ${ }^{56}$ the CRK.

As indicated earlier, there should be a clear dividing line between state and religious organisatioins in certain aspects. The principal of secularism ensures and promotes such division. This is also reiterated by the Court which provides that, "the principal of secularism, as provided in Art. 8 of CRK, contemplates that the State and religious organisations operate separately within each's own sphere and they do not exercise authority over the affairs of the other. Thus, secularism permits religious organisations to conduct their affairs without undue interference from the State and religious organisations cannot mandate what the state can or cannot

52 See Article 38 (2) CRK.

53 Ibid. Article 38 (4).

54 Marko, Joseph. (2008) The New Kosovo Constitution in a Regional Comparative Perspectice, Review of Central and East European Law, Martinus Nijhoff Publishers, p. 447, available at: http:// www.observatori.org/paises/pais_55/documentos/The\%20New\%20Kosovo\%20Constitution\%20in\%20 Regional\%20Comparative\%20Perspective.pdf

55 Sajó, András. (2008) Preliminaries to a Concept of Constitutional Secularism, Oxford University Press \& New York University School of Law, Vol. 6, No. 3 \& 4, p. 615.

56 Sajó, András. (2008), p. 616. 
legislate for.That is not to say that religious organisations are excluded from debate within issues in the public sphere or to say that the State is forbidden to regulate matters within its constitutional remit." ${ }^{57}$ Finally, the significantrole of the principle of equality, non-disrimination and principle of secularism as reflected in the CRK, convey the basis for recognition of the diversity, religious freedom, beliefs, and provides the structure for the preservation of such fundamental human rights. Such advancement of the rights of individuals and groups represent the values that sustain the rule of law in Kosovo as a young democratic state.

\section{ECONOMY AND PROTECTION OF PROPERTY}

The Republic of Kosovo has embraced the new economic order based on the market economy. This marks a shift from the previous planned economy that Kosovo has been part of until the fall of the socialism. However, the new economic order has been something that drafters paid particular attention by making it a constitutional principal. In this regard, the CRK proclaims that, "A market economy with free competition is the basis of the economic order of the Republic of Kosovo." 58

It is of equally importance to note the designation of the state to ensure the legal mechanisms for ensuring the preconditions for a free market economy. Such commitment is extensively enshrined in the provisions of the CRK. As noted earlier, the CRK has established the core principles for ensuring a favorable legal environment for a market economy, freedom of economic activity and safeguards for private and public property. ${ }^{59}$ Considering the importance of the foreign direct investments in reviving Kosovo's economy, the CRK has acknowledged equal legal rights for foreign investors as domestic investor has for conducting business.

Regarding the protection of property and property rights as a particular form of economic human rights, the CRK guarantees the right to own property for all its citizens. It also protects the owners of the property rights against restriction of property and from being deprived of their property rights. This restriction and deprivation of property may arise in the cases of state expropriation of private property for public interest. In this case, prior to beginning the process of expropriation, the CRK requires that the basic elements of the expropriation should be met, that are public interest, legal basis, and adequate compensation to the person or persons whose property has been expropriated. ${ }^{60}$

57 See Judgment in Cases KO 45/12 and KO 46/12, date 24 June 2012, Request of Liburn Aliu and 11 other Members of the Assembly of the Republic of Kosovo for constitutional assessment of the Law on the Village of Hoce e Madhe/ Velika Hoca and the Law on the Historic Centre of Prizren, paragraph 65, available at: https://gjk-ks.org/wp-content/uploads/vendimet/gjk_ko_45_46_12_ang.pdf

58 See Article 10 CRK.

59 See Article 119 (1) - (10) CRK.

60 See Article 46 (1)(2)(3) CRK. 


\section{CONCLUSION}

The CRK is regarded as a determining element in establishing Kosovo as an independent state. Despite the difficult process that was conducted prior to its adoption, the CRK has accomplished its goal by setting the fundamental principles through which the Republic of Kosovo is being governed. In spite of its short existence from the adoption, the CRK has gone through some changes which are related primarily to termination of international supervision upon domestic public institutions after the declaration of the Independence in 2008.

However, the CRK in its current social, economic, and political situation has been able to achieve its intention by establishing the Republic of Kosovo as an independent country, equality for all its citizens, and also which is very important an excellent example in the region for the high level of legal protection of the basic rights to all the minorities wholive in Kosovo.

In addition, the CRK and its amendments enshrine in itself basic principles that are the foundation for the rule of law. These constitutional principles have further extended in the provisions of other laws and also have been established institutional structures for their adequate enforcement. The Court has played a prominent role through its establishment of case-law as well. In this regard, the Court has served as a safeguard for advancing the application of such principals in line with the spirit of the constitution. Finally, the enforcement of constitutional principles remains a continued process, and in order to have a practical impact, it is requires the involvement of the entire institutional structure and all the communities in Kosovo.

\section{BIBLIOGRAPHY}

\section{Books, Scientific Papers and Reports}

1. Galluci, M., Gerard. (2011) The Ahtisaari Plan and North Kosovo, Transconflict, available at:http://www.transconflict.com/10/wp-content/uploads/2011/11/Policy Paper_AhtisaariPlanNorthKosovo.pdf

2. Jackson, C., Vicki \& Tushnet, Mark. (2014) Comparative Consitutional Law, 3rd ed., University Casebook Series.

3. United Nations, Security Council (2007) Comprehensive Proposal for the Kosovo Status Settlement, ANNEX I, available at: https://www.securitycouncilreport.org/ atf/cf/\%7B65BFCF9B-6D27-4E9C-8CD3-CF6E4FF96FF9\%7D/Kosovo\%20 S2007\%20168.Add1.pdf

4. Yu, Ho., Chong \& Cheung, Tung., Kwok. (2017) Rethinking the Dworkinian ForwardLooking Approach: is Affirmative Action Compatible with Fairness, European Journal of Social Sciences Education and Research, Sep. Dec. 2017 Vol.11 Nr. 2, available at: https://www.researchgate.net/publication/320586791_Rethinking_the_ Dworkinian_Forward-Looking_Approach_is_Affirmative_Action_Compatible_ with_Fairness 
5. DeBell, Matthew. (2006) Affirmative Action in Higher Education: Insults, Preferences, and Affirmative Action in Higher Education: Insults, Preferences, and the Dworkin Defense, American National Election Studies, Stanford University, Volume 85, Issue 2, p. available at: https://digitalcommons.unl.edu/cgi/viewcontent. cgi? article $=1119 \&$ context $=$ nlr

6. Freeman, Michael. (2014) Lloyd's Introduction to Jurisprudence, Sweet and Maxwell, 9th ed.

7. Weller, Marc. (2009) Contested Statehood: The International Administration of Kosovo's Struggle for Independence, Oxfort University Press.

8. Tridimas, George. (2009) Constitutional Judicial Review and Political Insurance, European Journal of Law and Economics, DOI: 10.1007/s10657-009-9112-z, p. 97 , available at: https://www.researchgate.net/publication/225759546_Constitutional_ judicial_review_and_political_insurance

9. Marko, Joseph. (2008) The New Kosovo Constitution in a Regional Comparative Perspectice, Review of Central and East European Law, Martinus Nijhoff Publishers, p. 447, available at: http://www.observatori.org/paises/pais_55/documentos/The\%20 New\%20Kosovo\%20Constitution\%20in\%20Regional\%20Comparative\%20 Perspective.pdf

10. Sajó, András. (2008) Preliminaries to a Concept of Constitutional Secularism, Oxford University Press \& New York University School of Law, Vol. 6, No. 3 \& 4

\section{Legal Acts}

1. Constitution of the Republic of Kosovo, available at: http://www.kryeministri-ks.net/ repository/docs/Constitution1Kosovo.pdf

2. Constitutional Framework for Provisional Self-Government, available at: https:// www.esiweb.org/pdf/bridges/kosovo/12/1.pdf

3. Amendment No. 24 to the Constitution of the Republic of Kosovo, Official Gazette of the Republic of Kosova, No. 20/05 August 2015, Prishtina, available at: https://gzk. rks-gov.net/ActDetail.aspx?ActID=3702

4. Law No. 04/L-115 on Amending and Supplementing the Laws related to the ending of International Supervision of Independence of Kosovo, available at: https://gzk. rks-gov.net/ActDetail.aspx?ActID=2840

5. UNMIK Regulation 1999/24, 12 December 1999, available at: https://unmik. unmissions.org/sites/default/files/regulations/02english/E1999regs/RE1999_24.htm

6. Law No. 06/L-055 on Kosovo Judicial Council, Official Gazette of the Republic of Kosovo, No. 23/26 December 2018, Pristina, available at: https://gzk.rks-gov.net/ ActDetail.aspx?ActID=2713

\section{Case-law}

1. Judgment in Case No. KO43/19, dt. 27 June 2019, Aplicants Albulena Haxhiu, Driton Selmanaj and thirty other deputies of the Assembly of the Republic of Kosovo, available at:https://gjk-ks.org/wp-content/uploads/2019/06/ko_43_19_agj_ang.pdf 
Nur Çeku \& Haxhi Xhemajli: Constitutional principles and their impact on the establishing of the... Zbornik radova Pravnog fakulteta u Splitu, god. 57, 4/2020, str. 1079-1096

2. Judgment in Case No. KI 47/10, date 28 September 2010, Applicants Naim Rrustemi and 31 other Deputies of the Assembly of the Republic of Kosovo, available at: https://gjk-ks.org/wp-content/uploads/vendimet/ki_47_10_eng_2.pdf;

3. Judgment in Case No. KO 01/09, date 18 March 2010, Applicants Qemajl Kurtishi v. Municipal Assembly of Prizren, paragraph 52, available at: https://gjk-ks.org/wpcontent/uploads/vendimet/ko_01_09_Ven_ang.pdf

4. Judgment in Case No. KO 119/10, date 8 December 2011 Applicant Ombudsperson of the Republic of Kosovo, available at: https://gjk-ks.org/wp-content/uploads/ vendimet/gjk_ko_119_10_ang.pdf

5. Judgment in Cases KO 45/12 and KO 46/12, date 24 June 2012, Request of Liburn Aliu and 11 other Members of the Assembly of the Republic of Kosovo for constitutional assessment of the Law on the Village of Hoce e Madhe/ Velika Hoca and the Law on the Historic Centre of Prizren, available at: https://gjk-ks.org/wp-content/uploads/ vendimet/gjk_ko_45_46_12_ang.pdf

\section{USTAVNA NAČELA I NJIHOV UTJECAJ NA USPOSTAVU USTAVNOG PORETKA I VLADAVINE PRAVA NA KOSOVU}

Ustav Republike Kosovo, koji se smatra progresivnim dokumentom zasnovan na modelima zapadnih ustava, uspostavio je pravnu osnovu za funkcionalnu državu koja poštuje prava i temeljne slobode, a istovremeno jamči vladavinu zakona. U svojim odredbama Ustav je postavio osnovna načela koja služe kao temelj ustavnog poretka Kosova. S tim u vezi, ova ustavna načela dalje su ugrađena u odredbe zakona koji proizlaze iz Ustava, a uspostavljena su i u institucionalnim mehanizmima za njegovu primjerenu primjenu. Uz to, ono što je imalo istaknutu ulogu u definiranju ovih načela bio je utjecaj sudske prakse Ustavnog suda. Sudska praksa je u mnogim slučajevima potvrdila ogromnu važnost ustavnih načela u jačanju vladavine prava, zaštiti prava manjinskih skupina i ostalih članova kosovskog društva, te prava na slobodu vjerovanja i sekularizma primjenom najmodernijih europskih standarda u ljudskoj zaštiti. U članku se analizira utjecaj koji su ustavna načela imala na definiranje strukture države, jamstva vladavine prava, zaštitu ljudskih prava i izgradnju Kosova kao multietničkog društva. U radu se također preispituje praksa Ustavnog suda Kosova ukazivanjem na najistaknutije odluke.

Ključne riječi: Ustav, ustavna načela, sudska praksa, Ustavni sud, vladavina prava, programi afirmativne akcije, ljudska prava 